This is an electronic reprint of the original article. This reprint may differ from the original in pagination and typographic detail.

Author(s): Seppälä, Riina

Title: Learner agency within the design of an EAP course

Year: $\quad 2015$

Version:

Please cite the original version:

Seppälä, R. (2015). Learner agency within the design of an EAP course. In J. Jalkanen, E. Jokinen, \& P. Taalas (Eds.), Voices of pedagogical development : expanding, enhancing and exploring higher education language learning (pp. 197-222).

Research-publishing.net. https://doi.org/10.14705/rpnet.2015.000293

All material supplied via JYX is protected by copyright and other intellectual property rights, and duplication or sale of all or part of any of the repository collections is not permitted, except that material may be duplicated by you for your research use or educational purposes in electronic or print form. You must obtain permission for any other use. Electronic or print copies may not be offered, whether for sale or otherwise to anyone who is not an authorised user. 


\title{
10 Learner agency within the design 1 of an EAP course
}

\author{
Riina Seppälä ${ }^{1}$
}

\section{Abstract}

$\mathrm{T}$ o meet the demands of today's society and working life, higher education should support the development of learner agency. How the agency of individual learners emerges in university courses and what kind of agency empowers the learners to face new challenges should be considered. In this article, the focus is on learner agency enabled and expressed on a higher education language course. One learner's experiences of a blended English for Academic Purposes (EAP) course are explored and used to examine the design of the course. The data reveal that the learner's views of language-use categories and of herself as a language user emerged as central parts of her agency. Although the learner was, in many respects, an active agent on the course, she seemed to be restricted by the assumed expectations of academic language use. Thus, empowering agency was not expressed within the course design. The Design-Based Research (DBR) approach employed in the study enables changes to the learning design to better support the development of empowering agency. Examples of such changes include discussing different learner positions on academic courses and supporting learners' reflections on the relevance of the course. DBR as a strategy to support teachers' agency is also discussed.

Keywords: agency, design, design-based research, English for academic purposes.

1. Language Centre, Aalto University, Finland; riina.seppala@aalto.fi

How to cite this chapter: Seppälä, R. (2015). Learner agency within the design of an EAP course. In J. Jalkanen, E. Jokinen, \& P. Taalas (Eds), Voices of pedagogical development - Expanding, enhancing and exploring higher education language learning (pp. 197-222). Dublin: Research-publishing.net. doi:10.14705/rpnet.2015.000293 


\section{Introduction}

Constant changes and developments in today's society and working life require skills and resources different from those needed before (Conole 2012; Kalantzis \& Cope 2001, 2004; Sawyer 2006; Taalas, Tarnanen \& Huhta 2007; Tynjälä 2011). It is increasingly important for individuals to be able to adjust to and learn in novel situations and contexts throughout their lives (Kalantzis \& Cope 2001, 2004; Sawyer 2006; Tynjälä 2011). This need is also reflected in the requirements placed on the education system, particularly on higher education, because students proceed to the labour market during or after their studies.

Higher education students, preparing to work as experts in their own field, should be able to exercise their agency to meet new challenges and to undertake the responsibility of maintaining their own expertise. Agency to construct one's own learning and expertise should therefore be supported and promoted during university studies. The question then arises of how the agency of individual learners emerges in university courses and what kind of agency empowers learners to face new challenges. In this article, the focus is on one learner's agency on a higher education language course and the way it relates to the notion of life-long learning. The research questions are as follows: (1) What kind of learner agency is enabled and expressed within the design of an EAP course from the point of view of one learner? (2) How does the learning design support or restrict the development of the type of agency needed to maintain and expand learners' expertise? It should be noted, however, that this article examines learner agency from a limited, single-learner perspective. To further develop tertiary level studies, large-scale, in-depth research on learner experiences is needed.

\section{Dimensions of agency}

The conception of learners' intentional action to develop their skills and to discover the best ways to achieve that development are embedded in the concept 
of agency, which can be briefly described as the individual's "socioculturally mediated capacity to act" (Ahearn 2001: 112). Extensive research has been conducted on agency in different fields and with different emphases in the interrelationship between individuals and their environment. Some schools of thought place more stress on the environment and structures, and others concentrate on the inner processes of an individual in the emergence of agency. Due to the complexity of the concept, forming a thorough understanding of agency as well as grasping and benefiting from the significance of the research results in other contexts has been difficult. Even the brief definition by Ahearn (2001) extends in many directions and implies various processes that cannot be defined decisively. However, uncovering the concept of agency and its different forms and manifestations is crucial to be able to support life-long learning in education. So rather than providing a fixed definition of agency, constructing an understanding of agency based on its various dimensions could better illustrate the concept.

Drawing on previous studies, the central dimensions of agency include the initiative or intentional action (e.g. Hunter \& Cooke 2007; van Lier 2008) of individuals to reach personal goals (Kalaja, Alanen, Palviainen \& Dufva 2011). In addition, the accountability of individuals for their actions and the way in which these individuals are credited for their accomplishments could be viewed as another dimension of agency (Lipponen \& Kumpulainen 2011). Agency is also often seen as dynamic, emerging and shaped in and by interaction (e.g. van Lier 2008). In that sense, agency has been described by a number of authors (Ahearn 2001; Hunter \& Cooke 2007; Lantolf \& Thorne 2006; van Lier 2008; Wertsch 1991; Wertsch, Tulviste \& Hagstrom 1993) as being mediated by, for example, structures and tools. In addition, closely connected to the concept is individuals' sense of their own agency (see Bandura 1997 and 2001 on self-efficacy; van Lier 2008), that is, the way individuals feel they are able to "make a difference" (Mercer 2012: 41) in their own learning in a particular context. Mercer (2011, 2012) argues that agency consists of two components: the deliberate, agentic behaviour of the learners and their sense of agency. This would suggest that when exploring agency, observational and reflective data should be combined to capture these different components. 
Given the dynamic nature of agency, certain dimensions might emerge as central to individual learners in different learning contexts. In-depth case studies then become necessary to uncover how agency unfolds in specific situations. Moreover, taking into account the need for the new types of participation and individual development mentioned earlier, it is essential to explore what kind of agency would be truly empowering for learners to function in society and what kind of agency should, therefore, be supported through pedagogical choices and decisions for individual courses.

One specific change should be promoted across all educational levels. Following the notion of life-long and life-wide learning, crossing the boundaries between and connecting formal and informal contexts for learning should be encouraged (e.g. Luukka et al. 2008; Kalantzis \& Cope 2012). In this era of ubiquitous information and new literacies (e.g. Lankshear \& Knobel 2003; Cazden et al. 1996), learners should be able to draw on learning contexts from outside of formal education, and this ability should also be acknowledged by the educational system. In this way, focusing on the development of each individual would make learning more personalised and meaningful. Although attempts have been made to achieve this personalisation, the implementation is challenging. One reason might be that learners have usually been socialised into a certain type of a culture of learning for several years, and transforming that familiar and established culture is a lengthy process. Uncovering the roots underlying this difficulty, therefore, requires a more thorough understanding of the personalisation process. The current article is based on one higher education language teacher's design-based research process, aimed at understanding individual learners' experiences during university studies and contributing to the development of teaching practices. In this respect, two perspectives are adopted; that of an individual learner on an academic English course and that of the design.

\section{Design-based research strategy}

When considering supporting learners' agency from the perspective of a higher education language teacher, the design of courses is the main tool in the 
process. In this article, design is defined as the way in which the pedagogical course plan unfolds in the interaction between the learners and the teacher - in other words, how the design is "enacted" (Lund \& Hauge 2011: 262) in the course. Through this enactment, learner agency is contextualised and situated within the design.

One research strategy to support practitioners in this type of exploration is DBR, which aims at changing educational practices by researching learning in reallife contexts and developing learning designs through cycles of data collection, analysis and development (Barab \& Squire 2004; Design-Based Research Collective 2003; Edelson 2002; Sandoval \& Bell 2004; Wang \& Hannafin 2005). This cyclical approach allows researching how agency is enabled on an individual course but also immediately making changes in the learning design to better support learners. This might also facilitate implementation of significant changes in higher education.

As mentioned above, although the need for development in the education system has been recognised, implementing the change in, for example, language teaching, has been slow and difficult (Conole 2012; Ruohotie-Lyhty 2011a). One reason for this difficulty is that educational structures and the decisionmaking within them are usually complex. Another reason might be that if the terms of the change have been prescribed from above, practitioners might not have ownership of how the change should be brought about. Therefore, research conducted from within the system by, for example, teachers, would be particularly valuable: how individual teachers struggle with the new demands, how these themes materialise on individual courses and how they could best be tackled. Through DBR, these questions can be addressed. In addition, due to the combination of research, development and implementation, DBR allows new types of researcher profiles to emerge, as the dual role of a teacher-researcher is recognised and valued. Furthermore, teachers' experience and ethnographic data are often a natural part of DBR. Therefore, this type of research could support individual teachers' agency by giving them the opportunity to explore and raise new themes that are relevant for discussion from their perspective and by giving an example of a different career path of a teacher-researcher. 


\section{Finnish higher education as research context}

The research context in the current article is unique in the research on agency to date. For example, recent research on agency in language learning has largely focused on high school students (Wassell, Fernández Hawrylak \& LaVan 2010), language majors (Kalaja et al. 2011; Mercer 2011, 2012) and English as a Second Language (ESL) learners (Flowerdew \& Miller 2008). Skinnari (2012) has investigated the agency (and language learner identity construction) of primary school pupils in the fifth and sixth grade in Finland. Alanen et al. (2011) studied the agency of pre-service teachers majoring in languages during a Language Technology for Language Teachers programme, focusing on multimodal pedagogy. In the current article, the learner is not a language major but attends a university-level English course as a part of her studies. Blin and Jalkanen (2014) have explored university students' agency in a Finnish literacy skills course, taking a design perspective on language learning. University students' agency related to learning English has been studied by Basharina (2009, with a focus on online environments) and Murphey and Carpenter (2008). In Finland, language and communication studies are included in all higher education degrees. This means that all university students attend pre-determined language courses during their studies, in addition to the major and minor subject studies that they have chosen themselves. These courses are either compulsory ones tailored for students of a particular field or elective courses with different focuses (e.g. writing). This background offers a research setting to explore and increase understanding of the relationship students have with the focus of the courses and how that focus as well as course content could be better connected with their "life-world" (e.g. Kalantzis \& Cope 2004).

\section{Data and methods}

The course in question was an elective EAP course taught by a teacherresearcher. University students from all faculties could take the course as a part of the language and communication requirements of their degree. The course combined contact lessons (16 hours) with distance work, facilitated by a virtual 
learning environment. The course focused on academic writing as well as on learners' personal language learning beliefs and experiences. More specifically, factors affecting language learning were discussed on the course and the learners reflected on their own learning, strengths and weaknesses and their proficiency level in English. The course themes were discussed in academic papers written by the students, feedback was given on them and academic writing was discussed in class. Other course assignments included an independent learning project planned and implemented by the learners themselves as well as an oral presentation.

Following the typical features of DBR, various types of data were collected from the course in order to document it as thoroughly as possible from different perspectives. The data consist of all the course materials in the learning environment, the teacher's course and lesson plans and a reflective diary during the course, students' course assignments (including a reflective blog, academic texts, materials related to the independent learning project, videoed oral presentations), teacher and peer feedback on them, questionnaire answers collected during the course, emails related to the course, videoed contact lessons and learner interviews. First, qualitative content analysis (Dörnyei 2007) was conducted on the questionnaire and interview data in order to identify themes that emerged as relevant for learning. After that, one learner's data were scrutinised to truly get to the core of the dimensions of agency that emerged as central for the learner in question. As the learner attended a university course, these types of data can be seen as a kind of performance (a performance to the teacherresearcher, to the other learners). However, this has been acknowledged in the research process, because, to some extent, the learner probably builds a picture of the ideal learner through her answers. Even so, the data can still shed light on the learner's actions and views on the type of learning she assumes is aimed at in university studies and in this way they reveal some of the main challenges of higher education language education.

The learner focused on, in this article, is 'Katri' (a pseudonym). At the time of attending the course, she was finishing her bachelor's degree and later continued with her master's studies. She had earlier completed one compulsory English 
course and her proficiency level was approximately B2 based on the Common European Framework of Reference for Languages (Council of Europe 2013). Based on questionnaire and interview data as well as learner documents, Katri had clear career plans for herself and already had work experience in her field. She was chosen for a more detailed analysis, because her data clearly revealed her views on language use in different contexts. Her views are illustrative of some crucial contradictions learners on this course and other EAP courses might experience. In addition, she was able to reflect on her own views and experiences extensively during and after the course. As such, Katri's data provided a fertile ground for exploring the dimensions of her agency. Focusing on one learner also allows her experiences to be responded to in the design decisions in more detail.

\section{Language use categories underlying learner agency}

What became central in Katri's course experience were her descriptions of two language use categories: everyday language use and academic language use. More specifically, what seemed to define her experience was her relationship with those language use categories and, particularly, academic writing as the focus of the course. Her views were made explicit in various data types before, during and after the course. For example, in a questionnaire completed before the course's contact lessons began, Katri writes about her preferred ways of learning languages. In one of her replies, she clearly refers to a class environment: "I learn best by listening to others and taking notes. It's also good to talk with

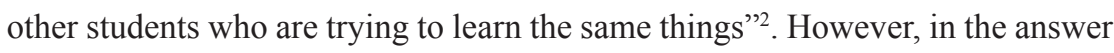
to the question "Describe yourself as a language learner" she highlights her preference for other types of learning situations: "I think I learn best in practice, for example during holidays when I have to use the language in everyday life. Too many assignments at school kill my motivation".

2. All examples taken from the learner's questionnaire answers and blog entries are direct quotations. Spelling errors have been corrected. 
Here, Katri emphasises being an everyday language user and suggests that the institutional, formal way of learning ("too many assignments at school") is not ideal for her. Similarly, when asked about how writing in English makes her feel, her answer is neutral: "It's quite normal. I don't feel anything special". However, when she is asked specifically about the kind of academic writer she thinks she is at the moment, she again stresses the difference between various contexts of language use: "Not so much an academic writer I guess, I have ways to go around the words I don't know in everyday life texts".

In a comparison to her skills in writing everyday life texts, Katri does not consider academic writing to be her strength. This dichotomy seemed to set the tone for her whole course experience, and it was also illustrated in her course goals, which learners were asked to record during or after the first contact meeting of the course. At this point, the learners had more specific information about the content and focuses of the course. Katri wrote that she would like to learn to write in a more formal style, know more academic vocabulary and cite sources appropriately. In addition, she wanted to change her attitude towards academic writing, so that it would stop feeling so stressful and difficult that it would "show in the text".

Based on these examples, Katri is aware of her own views and constructs her course experience around the premise that she does not identify with the focus of the course. This approach is also illustrated later when, in a reflective task, she was asked to assess her proficiency in English and write the self-assessment in her blog. She described the following situations and characteristics as some of her strengths in using English:

"Natural conversations...natural perspective towards English; I am not much of an academic English user, but I enjoy using the language in natural settings in school, work, and with my friends, I am not nervous in those situations at all and I am the one who always has something to say".

In addition, as her weaknesses she names not having the "occupational or personal need" to learn academic English because she already manages different 
everyday language use situations. In these comments, Katri again refers to academic English as something that does not feel relevant to her and she contrasts it with "natural settings". However, in those "natural settings" she also includes school and work. The comments seem, therefore, to highlight the conception that she does not see academic language use as a part of her life in any way - even her university studies or future work - and that, in this sense, it is not authentic language use for her. She described similar views in two semistructured interviews as well (Dörnyei 2007), which were conducted at the end of the course and six months later. In the interviews, she describes her own abilities in language use in the following ways:

[Katri answers a question on what kind of situations she uses English in at the moment]: "Speaking in English if I don't need any specific vocabulary - that I do best - if I don't remember a word I can always say it in another way $^{3}$.

I don't really regard myself as an academic writer - when I write it is difficult for me not to express my own opinion - I would just like to bring my own point of view into it".

Here, Katri gives reasons for enjoying speaking English in everyday situations: the communication is natural in the sense that she is able to express her own opinion and she does not have to be concerned about mistakes. The ideal topics would be related to something deeper than, for example, work. In those discussions, she would be able to exchange experiences and impressions with another person as well as describe her feelings. Some of the language learning goals described by her were connected with these views: for example, learning new vocabulary in order to express her feelings and opinions using rich language.

At the same time, Katri's descriptions shed some light on why academic language use makes her anxious. She implies that more formal language use situations

3. All examples taken from the interviews were originally in Finnish and have been paraphrased in English by the researcher. 
have stricter rules and norms that she is perhaps not able to follow. These include situations in which "specific vocabulary" is needed, accuracy is expected, and in which making a mistake would be a cause for embarrassment. In addition, she sees that requirements related to references and even the use of commas are imposed on language users, and expressing one's own opinions is not allowed.

What is interesting is that although academic writing is not relevant in Katri's life, she still set goals for herself to change her way of thinking. Here Katri describes her course goals:

"The last two [goals] were intertwined so that the use of sources would just become like 'I'll just search for a source and put it there' - and that it wouldn't be like 'oh no, not the bibliography again, how do I do this, how about commas, how about dates' - and if we talk about essays, research proposals, theses, academic texts, that I wouldn't feel like 'this is the difficult task again' but I would just start to write instead - and that I would just do that and that's it - a kind of change in my attitude - that I do not have to stress about it".

As her answer shows, it is clearly the formal context of language use that is focused on in this university course, so Katri needs to adjust to it by changing her attitude.

\section{Attitude to language use categories as a means to construct learner identity}

In addition to defining her own preferences and goals in relation to these different categories of language use, Katri also presents and defines herself in relation to the same categories in the interviews, questionnaire answers and blog texts. This type of reflective data (e.g. interviews, questionnaires, diaries) has been made use of in earlier agency research (e.g. Flowerdew \& Miller 2008; Lasky 2005; Murphey \& Carpenter 2008; Ruohotie-Lyhty 2011a, 2011b; Vähäsantanen, Saarinen \& Eteläpelto 2009) in order to gain insight into how the individuals, in 
their own words, describe their personal experience and the way in which they perceive the situation. This emphasises agency as being constructed through an individual's own experiences and perceptions (e.g. Ruohotie-Lyhty 2011a). It also aligns with Dufva and Aro's (2014) dialogical view on agency in language learning. Drawing on, for example, Sullivan and McCarthy (2004), Dufva and Aro (2014) have discussed a dialogical perspective on agency in learning English, placing importance on the personal stories and lived experiences of an individual and focusing on the fluidity of agency of those individuals in time and space. This type of emphasis on the personal experiences sheds light on learner agency in Katri's case as well.

From this perspective, agency is closely connected to identity construction, especially if identity is defined according to Norton's (2000) view, in which it consists of the way an individual sees and constructs the relationship between oneself and the world, and one's possibilities for the future. This relationship is dynamic as it is reshaped, for example, during the learning process (Norton 2000; Norton Peirce 1995; see also Lave 1993). The view is shared by van Lier (2007), who defines identity as new ways of relating the self to the world. Individuals perceive situations, decide on their own actions and interpret experiences in their own way. Similarly, in the interviews, questionnaire answers and blog texts, Katri was describing her relationship to using English.

Ruohotie-Lyhty (2009) has conducted similar research using interview data on newly qualified teachers and their agency during the first years in working life. According to Ruohotie-Lyhty (2009), teachers acted in different work-related situations based on how they, from the perspective of their own backgrounds, saw and understood those situations. This approach, in turn, shaped their agency. Ruohotie-Lyhty $(2009,2011 b)$ connects this finding to Bandura's (1997) as well as Holland, Lachicotte, Skinner \& Cain's (1998) views. For example, Holland et al. (1998) suggest that agency is rooted in individuals' expertise and how they identify themselves with the expert community. How individuals view themselves and their expertise determines how different situations are perceived and, as a consequence, how those situations are addressed. This is closely connected to Bandura's $(1997,2001)$ views on self-efficacy. Although Ruohotie- 
Lyhty's (2009, 2011b) study focused on teachers instead of learners, a similar situation emerged in the present study, as Katri's own perceptions seemed to shape her actions and experiences on the course. Based on the data excerpts, Katri described herself as someone clearly belonging to the group of everyday language users and, at the same time, excluded herself from the expert group of academic language users. What she saw as the focus of the course contradicted her ideal language use and the identity and expertise she associated with herself.

\subsection{Assumptions of preferred agency}

Despite the perceived contradiction, Katri clearly tried to make sense of academic language use when working on the course assignments. She expressed some uncertainty about the proper way to complete the assignments. For example, after the second contact meeting of the course, Katri went to talk to the teacher. She explained that she felt some of the instructions for the written assignments were not always clear regarding language use and style. She mentioned that based on what she knew about academic writing - having even consulted a friend about it - the use of passive voice is often recommended. Katri did not know whether to write the texts using the first person pronoun (I) or if more objective language use was preferable. The teacher tried to guide Katri in class by explaining that as the topics of the written assignments were related to the students' own experiences in language learning, the style of the texts could reflect that.

When writing the third assignment, a synthesis, Katri contacted the teacher via email, asking for advice on how to write such a text. The text type seemed to be unfamiliar to her and she wanted to know how to correctly incorporate the different sources of information. In this way, Katri seemed to find it important to ensure that she followed the instructions of the assignment thoroughly and fulfilled the expectations for academic writers. Based on the questionnaire answers of all students, the text type was unfamiliar to most of them, but Katri was still the only one who asked for more detailed instructions. Considering that she did not see the relevance of academic writing in her life, she still made attempts to complete the academic writing assignments as carefully as possible, 
suggesting some type of investment in and intentional action for completing the assignments well. This effort highlights the type and complexity of Katri's agency on the course. It is possible that she assumed that merely following the rules to complete the assignments was the preferred type of agency for the learners.

\subsection{New positioning: learner agency in mastering academic writing}

Katri's views on these different types of language use and her efforts to figure out the features of the more distant language use category were also illustrated in her descriptions of her successes and accomplishments in the course. For example, in the questionnaire filled in during the final contact meeting of the course, she replied:

"My views related to reading and writing academic texts and incorporating sources have changed in the way I hoped: they are like any other texts, and it is not so stressful anymore, because I have gained new tools and good feedback".

Here Katri describes how her view of academic texts has changed. In the interviews, she went into more detail on how she viewed them and how she felt when completing academic reading or writing assignments:

"If I had to start writing something - a thesis, a research paper - I have an idea of what the paragraphs are supposed [emphasis by author] to be, what kind of vocabulary I should use and not use - what the bibliography looks like - maybe some kind of models in my head - I already have some kind of an idea of what is expected of me.

Well I really did learn what I was supposed to learn - that I do not have to stress about them [academic texts] - that even if someone says 'academic something' and talks about references and certain formats and how something should be done then fine, I just write it and that's it (laughs)". 
Katri describes succeeding in adjusting her language use to meet the requirements of a different genre. She, in a way, describes being able to gain access to the group of academic language users to the extent that she needed to in order to complete the course assignments and to write her thesis later on. In that sense, she was extending her own language use repertoire as she gained resources for academic writing.

What Katri described was a change in the relationship between herself and the focus of the course: as she became better able than before to manage academic language use situations, she was able to relate herself to the world in a new way (Norton 2000; Norton Peirce 1995; van Lier 2007). She saw those situations as ones with predetermined rules with little room for adjustments, but once she mastered them, she felt less stress. The introduction to concrete rules and guidelines became central to Katri's agency on the course. Through her own perception, she reported new ways to function in that context (the world of academic writing) and described herself as someone who knows what she is supposed to do (illustrated in the use of words such as supposed, should, expected), for example, when engaged in the process of writing her thesis.

\section{The frames set for learner agency through the design}

Despite the new ways in which Katri described her own actions, she still explained the focus of the course itself (academic writing) through its rules and restrictions. In that sense, her agency could be seen as rather limited, because her writing was directed by those restraints. Because this view emerged from other learners' data as well, these learner experiences gave reason to explore the design of the course and how the focus of the course is presented through it. In this exploration, the following questions were considered: Was there some aspect in the design that emphasised academic language use in this way and formed a basis for those learner descriptions? Did the design of the course restrict other views? 
When considering this interrelationship between the design of an individual course and learner experiences in it, the idea of positioning could be applied. According to Harré and van Langenhove (1999), positioning refers to the way in which we assign certain dynamic "roles" or "parts" to ourselves and others in, for example, a conversation. Individuals can position themselves in relation to others, or in relation to the "action" one is engaged in. Language learning and language use could be examples of such action. An individual can also be given certain positions by others, which can be assumed or rejected. This idea of positioning in relation to agency has been employed earlier by, for example, Lipponen and Kumpulainen (2011). They stress that instead of being stable, positions are constructed and reconstructed. Following this, Lipponen and Kumpulainen (2011) conducted research on positions that pre-service teachers took and were given and how those positions were created and transformed in situated discourse practices on a course related to their studies. For example, teachers may give authority to students by positioning them as experts in a conversation and by positioning themselves as belonging to the same group as the students.

Here, the notion was first utilised in exploring the way in which Katri positioned herself as a language learner and language user in relation to the focus of the course. Another way to employ the theory is to examine the positions that are available or given to the learners on the course through its design - in the course materials and feedback given to them on the course assignments. On this EAP course, academic writing as the main focus of the four contact meetings was made explicit through the course materials (e.g. lesson plans, the teacher's slides and other materials saved in the learning environment). For example, academic writing was defined at the beginning of the course through its features, and the assessment criteria for the course assignments were introduced then. Many of the features were discussed during the course through concrete examples in texts and short writing tasks given to the learners. For example, in the first two contact meetings, academic text types and their structures as well as citation practices were introduced, while the second meeting focused on formal style as well as on online dictionaries and thesauruses as tools in editing texts. The writer's voice, hedging, coherence and cohesion were also discussed on the course. Although 
the purpose of these themes was to make the genre of academic writing more concrete and accessible for the learners, it could also have been perceived as a list of requirements on how the course assignments should be completed appropriately, following all the guidelines. This is what the teacher also noticed during the course. The purpose of academic writing was returned to in the third meeting, because the teacher felt that the purpose behind the writing process had been overlooked. Therefore, the learning design was changed so that the topic was returned to halfway through the course.

When giving feedback on the written assignments, the teacher tried to focus on various elements of academic writing introduced in class. For example, based on analysis of the feedback given on Katri's academic texts, the feedback focused not only on, for example, the style and the structure of the texts and grammar but also the progression of ideas and the way in which conclusions were drawn at the end of the paper. The teacher acknowledged the critical approach that Katri had adopted on one topic and pointed out her strengths in writing an argumentative text. The teacher also commented on Katri's ability to make use of the feedback given to her in the earlier assignments. The teacher encouraged her to view the comments as recognition of her hard work.

Although the feedback was intended to help the learner consider various aspects of academic writing, it did not seem to have an effect on Katri's views. Actually, what was alarming for the teacher was that Katri did not once describe academic writing or academic language use as communication. Despite efforts to portray academic writing as a way to express one's views and to present one's arguments in a specific context, it was not seen or, rather, was not described as such by Katri. It might be that her earlier views on the nature of academic writing were too strongly ingrained to be changed during one course. However, considering the actual course content (e.g. themes of the contact lessons and the instructions given for the writing assignments), much of that might still have been perceived as restrictions on writing at the expense of the idea of communication.

These ideas on the nature of language and communication should have been discussed, because the academic context was not the most relevant one for 
all learners. As Katri's case shows, for those outsiders, this perhaps presented problems in terms of learner agency: how to connect one's identity and one's views of the course focus so that the course experience would be meaningful.

Although the research setting was different, Lasky's (2005) observations in a study on the interaction of reform mandates with teacher identity resemble those in Katri's case. In survey and interview data of experienced teachers in the midst of educational reform, Lasky (2005) observed a "disjuncture" between the teachers' identity and the assumptions that were embedded for their role in the mandates for reform. This restricted teachers' agency in the reform context. Still, despite the new expectations related to the reform, their sense of identity as teachers, which had developed over the years, was not altered. In one sense, a similar situation seemed to occur with Katri on the EAP course in how she experienced a disjuncture between her own identity and the expectations embedded in academic writing assignments.

\section{Insights into agency within the design of the EAP course}

This individual learner's experience provides important insights into the type of agency expressed on this EAP course and the type of empowering agency that should be supported on other higher education language courses. First, Katri's experience highlights the complexity of the learning situation and of the interrelationship between individual learners' agency and design. The design of the course carries certain expectations and assumptions related to the focuses of the course as well as the learners. There is potential for meaningful learning to take place, but, at the same time, the assumptions are not always verbalised, made explicit or challenged. In addition, those expectations are not necessarily realised when the design is enacted on the course. Through the design, the teacher did not want to portray academic writing - or any language use on her courses - in the way that Katri saw it, but it was still Katri's experience. She most likely had these views of everyday and academic language use also before the course, but the design of the course did not succeed in highlighting 
the underlying purpose of communication in different contexts: conveying one's own views. To support the development of higher education language teaching, the course design should, at the very least, enable and afford the emergence of empowering agency, not hinder or restrict it.

However, considering the dimensions of agency presented earlier, Katri was in many respects an active agent on the course: she completed extensive independent assignments, initiated interaction with the teacher on several occasions, set her own goals at the beginning of the course, worked purposefully to reach them and described having reached most of those goals (e.g. Kalaja et al. 2011). She also described her sense of agency (e.g. Mercer 2012) when she explained her course experience, and, for example, listed several features of a specific genre that she had apprehended. Nevertheless, the learning that Katri described was based on a view of academic language use as following specific rules even at the level of individual words. Her agency seemed to emerge through having concrete guidelines for language use that she could then adjust to, but the goal of that action merely seemed to be to complete the course assignments and it did not seem to be particularly meaningful outside the context of the course. Agency emerged and was operationalised within certain frames and it was limited by this mismatch of one's own skills and aspirations in relation to those perceived as the focus of the course. The design of the course did not therefore offer Katri possibilities for a different type of empowering agency. On the other hand, Katri, in her own way, gained access to academic language use. Although she did not see further use for it other than writing her thesis for graduation, that access might eventually become meaningful and more closely connected to her future life-world. Due to that possibility, longitudinal studies on learners' agency could shed light on the long-term development of learning paths (see Dufva \& Aro 2014).

One reason why the course focus failed to become meaningful for Katri might be that the formal and informal contexts of learning remained separate, and the boundaries between them were too clear and limiting. Drawing on the learners' own experiences and life-world was utilised when language learning experiences, views and needs were discussed on the course and were given as 
the topics of most of the writing assignments. However, it is possible that Katri perceived the main focus of the course to have been presented as only being related to formal contexts of language use, which alienated her and prevented her from constructing something meaningful within that context. In Katri's case, connecting her known life-world to the new in a meaningful way (Kalantzis \& Cope 2004) did not happen, with the result that her identity was not engaged (Kalantzis \& Cope 2004) in learning. One explanation for this might be that Katri, through years of being a part of a certain type of a culture of learning, had been strongly socialised into that way of studying, learning and using languages (see "school chronotype" in Dufva \& Aro 2014). Katri herself maintained this division in her own questionnaire answers, interviews and blog texts, because she might have thought that it was expected. Still, even in terms of the design of the course, the position the learners perceived as being offered by the course was probably too limiting. They did not view being positioned as academic writers without clear connections to their life-world as empowering.

\section{Implications for the design of higher education language courses}

Although this article focused on one learner's experiences on an EAP course, Katri's views on academic communication might be common among higher education students. Therefore, if teachers are aware of the language use categories that learners might have before attending an EAP course, it could help them avoid assigning learners to any predetermined positions from the start. For example, in the case of academic communication, different registers and language use situations certainly need to be focused on, as an expert of any field should be able to adjust one's language use based on the audience and context. However, those registers and language use situations should also be explicitly presented as possibilities and resources to extend the learners' language use repertoire instead of presenting merely the requirements of those situations. In addition, the design should challenge learners' existing views and any positions they might have already given themselves and which might limit their experience. One concrete way could be to negotiate with learners about the contents of a course and their 
own learning goals. The learners then become accountable for and capable of participating in the design of their own learning. This approach could promote a new type of learning culture. Learners could draw on their own life-worlds and exercise the type of agency that is needed today: to negotiate and construct a meaningful learning path for themselves. On the other hand, considering Katri's own interests in life and in language learning, the course was probably not the best choice for her. Timely study guidance could have supported her in finding an elective course which would have better fulfilled her ambitions. From the broader perspective of developing higher education language teaching, the course selection should include options with various focuses and cater for learners with diverse career plans.

Various ways to blur the boundaries of formal and informal contexts should also be explored, especially on courses that learners might initially see as formal or outside of their life-worlds (e.g. compulsory language courses). This shift needs to be made explicit and visible by, for example, offering anchors for reflection at various stages of a course, thereby helping learners localise themselves on their learning paths. Understanding the role or significance of, for example, an individual course on that path would support learners' life-long learning and help them better comprehend and articulate their own expertise. This could also strengthen the learners' sense of agency and their ability to adjust to rapid changes as well as help them make use of the situations that unavoidably come their way, such as compulsory studies. This is the form of agency that is needed in diverse contexts today.

This study contributes to the research on developing higher education teachers' expertise because, as a study conducted by a practitioner, it also supports individual teacher's agency by providing new tools for research-based development of one's work. In addition, the experience provided important insights into evaluating the suitability of the design-based research strategy in general. First of all, DBR allowed focusing on the learner experiences more thoroughly than regular collection of course feedback and observations in class would have. In fact, without in-depth research, Katri's struggle with the perceived contradictions in different types of language use might have gone unnoticed. In 
addition, DBR enabled quick changes to the design even during the course (e.g. discussing the purpose of academic writing), which aligns with the teacher's day-to-day work. The critical points that emerged from the data were also selected as focus points when developing the learning design. However, what is important is that the insights and development ideas need to be integrated into pedagogical discussion of the organisation. As a result, the research has the potential to inform and contribute to the expected learning outcomes and the content of higher education language and communication courses, higher education in general and to carry over into supporting students' life-long learning. In addition, DBR as a research strategy could support teachers' own agency in constructing their teacher identities by doing research related to their work, becoming aware of the challenges learners might face during their studies and developing learning designs to respond to those challenges.

\section{References}

Ahearn, L. M. 2001. Language and agency. Annual Review of Anthropology, 30, 109-137. doi:10.1146/annurev.anthro.30.1.109

Alanen, R., Huhta, A., Taalas, P., Tarnanen, M. \& Ylönen, S. 2011. Toimijuus ja asiantuntijaksi kasvaminen monimediaisessa kielenopettamisessa [Developing agency and expertise for multimodal language teaching]. In E. Lehtinen, S. Aaltonen, M. Koskela, E. Nevasaari \& M. Skog-Södersved (eds.), Kielenkäyttö verkossa ja verkostoissa [Language use in networks and on the net], AFinLA vuosikirja 69, AFinLA Yearbook 2011. Jyväskylä, Finland: AFinLa, 23-39.

Bandura, A. 1997. Self-efficacy: The exercise of control. New York, NY: W. H. Freeman.

Bandura, A. 2001. Social cognitive theory: an agentic perspective. Annual Review of Psychology, 52, 1-26. doi:10.1146/annurev.psych.52.1.1

Barab, S. \& Squire, K. 2004. Introduction: design-based research: putting a stake in the ground. The Journal of the Learning Sciences, 13 (1), 1-14. doi:10.1207/s15327809j1s1301_1

Basharina, O. 2009. Student agency and language-learning processes and outcomes in international online environments. CALICO Journal, 26 (2), 390-412.

Blin, F. \& Jalkanen, J. 2014. Designing for language learning: agency and languaging in hybrid environments. Apples - Journal of Applied Language Studies, 8 (1), 147-170. 
Cazden, C., Cope, B., Fairclough, N., Gee, J., Kalantzis, M., Kress, G., Luke, A., ... Nakata, M. 1996. A pedagogy of multiliteracies: designing social futures. Harvard Educational Review, 66 (1), 60-92. doi:10.17763/haer.66.1.17370n67v22j160u

Conole, G. 2012. Designing for learning in an open world: explorations in the learning sciences, instructional systems and performance technologies (Vol. 4). New York, NY: Springer.

Council of Europe. 2013. Common European Framework of Reference for Languages: Learning, Teaching, Assessment (CEFR). Retrieved from http://www.coe.int/t/dg4/ linguistic/cadre1_en.asp

Design-Based Research Collective. 2003. Design-based research: an emerging paradigm for educational inquiry. Educational Researcher, 32 (1), 5-8. doi:10.3102/0013189X 032001005

Dörnyei, Z. 2007. Research methods in applied linguistics. Oxford: Oxford University Press.

Dufva, H. \& Aro, M. 2014. Dialogical view on language learners' agency: connecting intrapersonal with interpersonal. In P. Deters, X. Gao, E. R. Miller \& G. Vitanova (eds.), Theorizing and Analyzing Agency in Second Language Learning - Interdisciplinary Approaches. Bristol: Multilingual Matters, 37-53.

Edelson, D. C. 2002. Design Research: what we learn when we engage in design. The Journal of the Learning Sciences, 11 (1), 105-121. doi:10.1207/S15327809JLS1101_4

Flowerdew, J. \& Miller, L. 2008. Social structure and individual agency in second language learning: evidence from three life histories. Critical Inquiry in Language Studies, 5 (4), 201-224. doi:10.1080/15427580802286173

Harré, R. \& van Langenhove, L. (eds.). 1999. Positioning theory: moral contexts of intentional action. Oxford: Blackwell.

Holland, D., Lachicotte, W., Skinner, D. \& Cain, C. 1998. Identity and agency in cultural worlds. Cambridge, MA: Harvard University Press.

Hunter, J. \& Cooke, D. 2007. Through autonomy to agency: giving power to language learners. Prospect, 22 (2), 72-88.

Kalaja, P., Alanen, R., Palviainen, Å. \& Dufva, H. 2011. From milk cartons to English roommates: context and agency in L2 learning beyond the classroom. In P. Benson \& H. Reinders (eds.), Beyond the language classroom. Basingstoke: Palgrave Macmillan, 47-58.

Kalantzis, M. \& Cope, B. 2001. New Learning: a charter for Australian education. Canberra: Australian Council of Deans on Education. 
Kalantzis, M. \& Cope, B. 2004. Designs for learning. E-Learning, 1 (1), 38-93. doi:10.2304/ elea.2004.1.1.7

Kalantzis, M. \& Cope, B. 2012. New learning: elements of a science of education (2nd ed.). Cambridge: Cambridge University Press. doi:10.1017/CBO9781139248532

Lankshear, C. \& Knobel, M. 2003. New literacies: changing knowledge and classroom practice. Buckingham: Open University Press.

Lantolf, J. P. \& Thorne, S. 2006. Sociocultural theory and the genesis of second language development. Oxford: Oxford University Press.

Lasky, S. 2005. A sociocultural approach to understanding teacher identity, agency and professional vulnerability in a context of secondary school reform. Teaching and Teacher Education, 21, 899-916. doi:10.1016/j.tate.2005.06.003

Lave, J. 1993. Situated learning in communities of practice. In L. B. Resnick, J. M. Levine \& S. D. Teasley (eds.), Perspectives on socially shared cognition (2nd ed.). Washington, D.C.: American Psychological Association, 63-82.

Lipponen, L. \& Kumpulainen, K. 2011. Acting as accountable authors: creating interactional spaces for agency work in teacher education. Teaching and Teacher Education 27, 812819. doi:10.1016/j.tate.2011.01.001

Lund, A. \& Hauge, T. E. 2011. Designs for teaching and learning in technology-rich learning environments. Nordic Journal of Digital Literacy 6 (4), 258-272.

Luukka, M.-R., Pöyhönen, S., Huhta, A., Taalas, P., Tarnanen, M. \& Keränen, A. 2008. Maailma muиttuu, mitä tekee koulu?: Äidinkielen ja vieraiden kielten tekstikäytänteet koulussa ja vapaa-ajalla [The world changes - how does the school respond? Mother tongue and foreign language literacy practices in school and in free-time.]. Jyväskylä: Jyväskylän yliopisto.

Mercer, S. 2011. Understanding learner agency as a complex dynamic system. System 39, 427-436. doi:10.1016/j.system.2011.08.001

Mercer, S. 2012. The complexity of learner agency. Apples - Journal of Applied Language Studies, 6 (2), 41-59.

Murphey, T. \& Carpenter, C. 2008. The Seeds of Agency in Language Learning Histories. In P. Kalaja, V. Menezes \& A. M. Barcelos (eds.), Narratives of Learning and Teaching EFL. New York, NY: Palgrave Macmillan, 17-34.

Norton, B. 2000. Identity and language learning: gender, ethnicity and educational change. Harlow: Longman.

Norton Peirce, B. 1995. Social identity, investment, and language learning. TESOL Quarterly, 29 (1), 9-31. doi:10.2307/3587803 
Ruohotie-Lyhty, M. 2009. Newly qualified language teachers' agency and professional development during the first years at work. In R. Kantelinen \& P. Pollari (eds.), Language education and lifelong learning. Joensuu: University Press of Joensuu, 279-303.

Ruohotie-Lyhty, M. 2011a. Constructing practical knowledge of teaching: eleven newly qualified language teachers' discursive agency. The Language Learning Journal, 39 (3), 365-379. doi:10.1080/09571736.2010.544750

Ruohotie-Lyhty, M. 2011b. Opettajuuden alkutaival - Vastavalmistuneen vieraan kielen opettajan toimijuus ja ammatillinen kehittyminen [First steps on the path of teacherhood. Newly qualified foreign language teachers' agency and professional development]. Doctoral dissertation. University of Jyväskylä, Jyväskylä.

Sandoval, W. A. \& Bell, P. 2004. Design-based research methods for studying learning in context: introduction. Educational Psychologist, 39 (4), 199-201. doi:10.1207/ s15326985ep3904_1

Sawyer, R. K. 2006. Introduction: the new science of learning. In R. K. Sawyer (ed.), Cambridge Handbook of the Learning Sciences. New York, NY: Cambridge University Press, $1-16$

Skinnari, K. 2012. "Tässä ryhmässä olen aika hyvä": ekologinen näkökulma kielenoppijaidentiteetteihin peruskoulun viidennen ja kuudennen luokan englannin opetuksessa [I'm quite good in this group". An ecological view to fifth and sixth graders' language learner identities in elementary school English language learning]. Doctoral dissertation. Jyväskylä studies in humanities 188. University of Jyväskylä, Jyväskylä.

Sullivan, P. \& McCarthy, J. 2004. Toward a Dialogical Perspective on Agency. Journal for the Theory of Social Behaviour, 34 (3), 291-309. doi:10.1111/j.0021-8308.2004.00249.x

Taalas, P., Tarnanen, M. \& Huhta, A. 2007. Oppilaat ja opettajat kielten ja tekstien käyttäjinä koulussa ja vapaa-ajalla - kartoitustutkimuksen suunnittelu ja toteutus [Pupils and teachers as users of languages and texts in school and out-of-school contexts - the planning and implementation of a survey]. In O.-P. Salo, T. Nikula \& P. Kalaja (eds.), Kieli oppimisessa - Language in Learning. Jyväskylä: Suomen soveltavan kielitieteen yhdistys AFinLA, 75-91.

Tynjälä, P. 2011. Asiantuntijuuden kehittämisen pedagogiikkaa [Pedagogy of developing expertise]. In K. Collin, S. Paloniemi, H. Rasku-Puttonen \& P. Tynjälä (eds.), Luovuus, oppiminen ja asiantuntijuus [Creativity, learning and expertise](1st-2nd ed.). Helsinki: WSOYpro, 79-95. 
Vähäsantanen, K., Saarinen, J. \& Eteläpelto, A. 2009. Between school and working life: vocational teachers' agency in boundary-crossing settings. International Journal of Educational Research, 48, 395-404. doi:10.1016/j.ijer.2010.04.003

van Lier, L. 2007. Action-based Teaching, Autonomy and Identity. Innovation in Language Learning and Teaching, 1 (1), 46-65. doi:10.2167/illt42.0

van Lier, L. 2008. Agency in the classroom. In J. P. Lantolf \& M. E. Poehner (Eds.), Sociocultural Theory and the Teaching of Second Languages. London: Equinox, 163-18.

Wang, F. \& Hannafin, M. J. 2005. Design-based research and technology-enhanced learning environments. Educational Technology Research and Development, 53 (4), 5-23. doi:10.1007/BF02504682

Wassell, B. A., Fernández Hawrylak, M. \& LaVan, S.-K. 2010. Examining the structures that impact English language learners' agency in urban high schools: resources and roadblocks in the classroom. Education and Urban Society, 42 (5), 599-619. doi:10.1177/0013124510375598

Wertsch, J. V. 1991. Voices of the mind: a sociocultural approach to mediated action. Cambridge, MA: Harvard University Press.

Wertsch, J. V., Tulviste, P. \& Hagstrom, F. 1993. A sociocultural approach to agency. In E. A. Forman, N. Minick \& A. S. Stone (eds.), Contexts for learning: sociocultural dynamics in children's development. New York, NY: Oxford University Press, 336-356. 


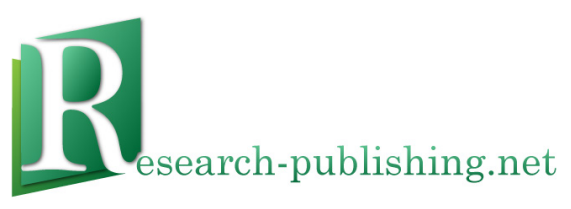

Published by Research-publishing.net, not-for-profit association Dublin, Ireland; Voillans, France, info@research-publishing.net

(C) 2015 by Research-publishing.net (collective work)

Each author retains their own copyright

Voices of pedagogical development - Expanding, enhancing and exploring higher education language learning Edited by Juha Jalkanen, Elina Jokinen, \& Peppi Taalas

Rights: All articles in this collection are published under the Attribution-NonCommercial -NoDerivatives 4.0 International (CC BY-NC-ND 4.0) licence. Under this licence, the contents are freely available online (as PDF files) for anybody to read, download, copy, and redistribute provided that the author(s), editorial team, and publisher are properly cited. Commercial use and derivative works are, however, not permitted.

\section{()ㅛ $\Theta \Theta$}

Disclaimer: Research-publishing.net does not take any responsibility for the content of the pages written by the authors of this book. The authors have recognised that the work described was not published before, or that it is not under consideration for publication elsewhere. While the information in this book are believed to be true and accurate on the date of its going to press, neither the editorial team, nor the publisher can accept any legal responsibility for any errors or omissions that may be made. The publisher makes no warranty, expressed or implied, with respect to the material contained herein. While Research-publishing.net is committed to publishing works of integrity, the words are the authors' alone.

Trademark notice: Product or corporate names may be trademarks or registered trademarks, and are used only for identification and explanation without intent to infringe.

Copyrighted material: Every effort has been made by the editorial team to trace copyright holders and to obtain their permission for the use of copyrighted material in this book. In the event of errors or omissions, please notify the publisher of any corrections that will need to be incorporated in future editions of this book.

Typeset by Research-publishing.net

Cover design by (C) Antti Myöhänen

ISBN13: 978-1-908416-25-4 (Paperback - Print on demand, black and white)

Print on demand technology is a high-quality, innovative and ecological printing method, with which the book is never 'out of stock' or 'out of print'.

ISBN13: 978-1-908416-26-1 (Ebook, PDF, colour)

ISBN13: 978-1-908416-27-8 (Ebook, EPUB, colour)

Legal deposit, Ireland: The National Library of Ireland, The Library of Trinity College, The Library of the University of Limerick, The Library of Dublin City University, The Library of NUI Cork, The Library of NUI Maynooth, The Library of University College Dublin, The Library of NUI Galway.

Legal deposit, United Kingdom: The British Library.

British Library Cataloguing-in-Publication Data.

A cataloguing record for this book is available from the British Library.

Legal deposit, France: Bibliothèque Nationale de France - Dépôt légal: septembre 2015. 